\title{
Nominations Accepted for the 2018 APSA Awards
}

S ubmit your nominations for the APSA dissertation, book, paper and article, and career awards, which will be presented at the 2018 APSA Annual Meeting in Boston, Massachusetts. The deadline for submission is Monday, February 12, 2018. For more information, visit apsanet. org/awards. The 2018 awards are listed below.

\section{GOODNOW AWARD}

The Frank J. Goodnow Award is made for distinguished service to the profession and the American Political Science Association, not necessarily a career of scholarship. This service may be by individuals, groups, or public and private organizations who have played a role in the development of the political science profession and the building of the association.

\section{CAREER AWARDS}

Bestowed for significant achievements related to political science.

\section{APSA Distinguished Teaching Award}

To honor outstanding contributions to undergraduate and/or graduate teaching of political science at two- and four-year institutions. The award recognizes contributions that have made a significant impact on the manner in which political science is taught or individual career contributions.

\section{John Gaus Distinguished Award and Lectureship}

Honors the recipient's lifetime of exemplary scholarship in the joint tradition of political science and public administration.

\section{Hubert H. Humphrey Award}

In recognition of notable public service by a political scientist.

\section{Benjamin E. Lippincott Award}

Recognizes a work of exceptional quality by a living political theorist that is still considered significant after a time span of at least 15 years since the original date of publication.

\section{Carey McWilliams Award}

Recognizes a major journalistic contribution to our understanding of politics.

\section{DISSERTATION AWARDS}

Departments are invited to submit nominations for dissertations that have been completed in the past two academic years.

\section{Gabriel A. Almond Award}

In the field of comparative politics.

\section{William Anderson Award}

In the field of federalism or intergovernmental relations, state, or local politics.

\section{Edward S. Corwin Award}

In the field of public law.

\section{Harold D. Lasswell Award}

In the field of public policy.

\section{Merze Tate Award}

In the field of international relations, law, and politics.

\section{E.E. Schattschneider Award}

In the field of American government.

\section{Leo Strauss Award}

In the field of political philosophy.

\section{Leonard D. White}

In the field of public administration.

\section{BOOK AWARDS}

Books published in 2017 may be nominated by individuals or publishers.

\section{Ralph J. Bunche Award}

For the best scholarly work in political science that explores the phenomenon of ethnic and cultural pluralism.

\section{Robert A. Dahl Award}

Awarded to an untenured scholar who has produced scholarship of the highest quality on the subject of democracy, including books, papers, and articles.

\section{Theodore J. Lowi Award}

For the best first book in any field of political science, showing promise of having a substantive impact on the overall discipline, regardless of method, specific focus of inquiry or approach to subject.

\section{Gladys M. Kammerer Award}

For the best political science publication in the field of US national policy.

\section{Victoria Schuck Award}

For the best book published on women and politics.

\section{Woodrow Wilson Foundation Award}

For the best book published in the United States in the field of government, politics, or international affairs.

\section{PAPER AND ARTICLE AWARDS}

Papers and articles published in 2017 may be nominated by individuals or publishers.

\section{Franklin L. Burdette/Pi Sigma Alpha Award}

For the best paper presented at the previous APSA Annual Meeting.

\section{Robert A. Dahl Award}

For an untenured scholar who has produced scholarship of the highest quality on the subject of democracy, including books, papers, and articles.

\section{Heinz Eulau Award}

For the best articles published in the American Political Science Review and Perspectives on Politics during the previous year. 